ISSN 0258-7122

Bangladesh J. Agril. Res. 37(2): 327-334, June 2012

\title{
PROFITABILITY OF HYBRID MAIZE (Zea mays L.) SEED PRODUCTION UNDER CONTRACT FARMING IN BANGLADESH: A FARM LEVEL STUDY
}

\author{
M. A. HAQUE ${ }^{1}$, MONIRUZZAMAN ${ }^{2}$, M. S. RAHMAN ${ }^{3}$ AND Q. M. AlAm ${ }^{4}$
}

\begin{abstract}
The study was conducted with three catagories of seed producers, namely BADC farms at Dattanagar, Jhenaidah and Tabunia, Pabna as public agency, LAL TEER Seed Company in Lalmonirhat district as private company and BRAC farm in Bogra district as NGO during Rabi season of 2007-08 to know the present status and profitability of hybrid maize seed production. A total of 60 hybrid maize seed contract growers and 120 maize (Non-seed) growers were selected randomly for the study. The cost of production was found higher for NGO (Tk. 66472/ha) than the public agency (64836/ha) and private company (Tk. 59352/ha). The yield of hybrid seed was highest under NGO (3780 kg/ha) than that of public agency and private company. Net return of hybrid seed production for contract growers was higher under public agency (Tk. 78204/ha) compared to private company (Tk. 39088/ha) and NGO (Tk. 33246/ha). Benefit cost ratio (BCR) was higher for the contract growers of public agency (2.21) Net return of hybrid maize seed production was $50 \%$ higher than that of non-seed production. High price of seed and lack of technical knowledge were major constraints of hybrid maize seed production in the study areas.
\end{abstract}

Keywords: Hybrid maize, profitability, net return and benefit cost ratio.

\section{Introduction}

Maize (Zea mays L.) is one of the most important cereal crops because of various uses of its grains and plants. Maize grain is a good source of the best and qualitative edible oil for human consumption. It is also a primary staple food for large proportion of people of developing countries. In regard to nutritive value, maize is superior to rice, but comparable to wheat with respect to certain food elements like fat and carotene maize is also better than wheat. In most western countries corn is used in preparing corn syrup and production of ethanol. It is also a good source of poultry and livestock feed.

As the demand for maize crop has been shifting increasingly in the world, particularly in the developing countries, its requirement will also increase from 282 million tons in 1995 to 504 million tons in 2020 (Pingali and Pandey, 2000). Now, it becomes an important cereal crop in Bangladesh like other countries. It stands $1^{\text {st }}$ among the cereals in terms of yield $5.24 \mathrm{~m}$ tons/ha. While the yield

${ }^{1}$ Senior Scientific Officer, ${ }^{2 \& 3}$ Scientific Officer and ${ }^{4}$ Chief Scientific Officer, Agricultural Economics Division, Bangladesh Agricultural Research Institute (BARI), Gazipur, Bangladesh. 
figures for wheat and rice were $1.53 \mathrm{~m}$ tons/ha and $2.52 \mathrm{~m}$ tons/ha, respectively (BBS, 2006). However, in the investigation of annual growth rate of area, production and productivity of maize, it was observed that the annual compound growth rates (CGR) were $42.20 \%$ for area, $63.20 \%$ for production, and $21.00 \%$ for yield, respectively, over last one decade and among the three components of maize production, the coefficient of variation of yield was the highest, which is more than 26\% (BBS, 2004).

The total shortage of seed was 3221 metric tons which occupied $72 \%$ of the total requirement of seed. In case of domestic seed production, Non- Government Organization produced $88 \%$, private companies produced $4 \%$ and public agencies produced $8 \%$ of the total production of seed (Islam, 2006). However, all these indicators revealed that in Bangladesh, maize production sector has an increasing and good potentiality of success. But for sustainable production of maize, a sound policy particularly for good seed production is essential and at the same time other production inputs and technology packages need to be ensured to the producers. So, in this regard, present study has been designed to conduct an investigation into the present hybrid maize seed production policy and constraints with the following specific objectives: to determine the input use pattern of hybrid maize seed at farm level; to estimate the profitability of hybrid maize seed production; to compare the profitability of hybrid maize seed production with hybrid maize production and to explore the problems of hybrid maize seed cultivation in Bangladesh

\section{Materials and Method}

The study was conducted at four locations, namely Dattanagar BADC farm in Jhenaidah district, Tabunia BADC farm in Pabna district (as public agency), LAL TEER Seed Company in Lalmonirhat district (as private company) and BRAC farm in Bogra district (as NGO ). The sample farmers (Contract growers) were selected with consultation of the concerned personnel of BADC, LAL TEER, and BRAC. They used hybrid varieties, such as BHM-5, Uttaran-I, Uttaran-II, 900M, Pacific-11, Pacific-60, Pacific-84, Pacific-759, etc. A total of 60 farmers (20 from BADC, 20 from LAL TEER, and 20 from BRAC) were interviewed for the purposes. For hybrid maize cultivation, 120 control farmers taking 30 from each location were selected randomly. They were used hybrid varieties, such as BHM-5, 900M, Pacific-11, Pacific-60, Pacific-84, etc. Data were collected by survey method with the help of pre-designed and pre-tested interview schedules during the Rabi season of 2007-08. The collected data were summarized and analyzed to fulfill the objectives set for the study. Tabular method of analysis using average, percentage, ratio, etc. was used. The opportunity cost of family supplied labour was taken into consideration in estimating total cost. In calculating gross margin, all operating costs were 
considered as variable cost. Total cost of production including total variable cost and total fixed cost. Total fixed cost was calculated on the basis of rental value of land. Profitability of hybrid maize seed production was examined on the basis of gross margin, net return and benefit cost ratio analysis.

\section{Results and Discussion}

\section{Inputs use pattern}

The study shows that human labour was the most important input in the seed production of maize. The total human labour used for producing maize seed were found 150 man days/ha of which 67 was family supplied and 83 was hired. The use of human labour in public agency was the highest (157man-days/ha), followed by private seed company (149 man-days /ha) and non- government organization (145 man-days/ha) (Table 1). The average cost of land preparation was Tk. 4752/ha. The land reparation cost was the highest in NGO (Tk 5024/ha)

Table1. Input use patterns in hybrid maize seed production at farm level.

\begin{tabular}{lcc|c|c}
\hline \multicolumn{1}{c|}{ Items } & $\begin{array}{c}\text { Public } \\
\text { agency }\end{array}$ & $\begin{array}{c}\text { Private seed } \\
\text { company }\end{array}$ & NGO & $\begin{array}{c}\text { All } \\
\text { categories }\end{array}$ \\
\hline Human labour (man- days/ha) & \multicolumn{4}{c}{} \\
Family & 62 & 65 & 74 & 67 \\
Hired & 95 & 84 & 71 & 83 \\
Total & 157 & 149 & 145 & 150 \\
Land preparation cost (Tk./ha) & & & & \\
Own & - & - & - & - \\
Hired & 4830 & 4402 & 5024 & 4752 \\
Total & 4830 & 4402 & 5024 & 4752 \\
Seed (kg/ha) & 20 & 19 & 22 & 20 \\
Cowdung (kg/ha) & 4918 & 5594 & 4570 & 5027 \\
Chemical fertilizers (kg/ha) & & & & \\
Urea & 541 & 525 & 535 & 534 \\
TSP & 249 & 247 & 246 & 247 \\
MP & 208 & 197 & 187 & 197 \\
Gypsum & 207 & 226 & 250 & 228 \\
Zinc & 12 & 13 & 8 & 11 \\
Borax & 6 & 5 & 4 & 5 \\
\hline
\end{tabular}

followed by public agency (Tk. 4830/ha) and Private seed company (Tk. 4402/ha). All farmers sowed seed in line. The sampled farmers used 
purchased seeds from BADC, BRAC and LAL TEER. On an average, the quantity of seeds used by the farmers were $20 \mathrm{~kg} / \mathrm{ha}$, the range varied from 19 to $22 \mathrm{~kg} / \mathrm{ha}$. They used cowdung from own sources. The average quantity of cowdung was $5027 \mathrm{~kg} / \mathrm{ha}$. The use of cowdung was the highest in private company (5594 kg/ha) and the lowest in NGO (4570 kg/ha). The used chemical fertilizers urea, TSP, MP, Gypsum, Zinc sulphate, and Borax at the rate of 534, 247, 197, 228, 11, and $5 \mathrm{~kg}$ per hectare, respectively. The application of urea was higher in public agency (541 kg/ha) than NGO (534 kg/ha) and private company (525 kg/ha). Similar trends were observed in case of TSP, MP, and Borax.

\section{Cost of hybrid maize seed production}

For estimating the cost of production of maize seed, all cost variable inputs like human labour, land preparation cost, seed, cowdung, fertilizer, insecticide, irrigation, interest on operating capital and land use cost, etc. were calculated on per hectare basis. The gross cost included total cost, total variable cost and cash cost. The average costs of seed cultivation were Tk. 63558, Tk. 51271 and Tk. 43178 per hectare on total cost, total variable cost and total cash cost basis, respectively (Table 3). The major share in gross cost was human labour (23\%) and fertilizer (23\%) followed by land use cost (17\%), seed cost (16\%), land preparation cost $(8 \%)$, and irrigation cost $(6 \%)$. The cost of production of contract growers under NGO was found higher than public agency and private company due to higher cost of seed, land use and insecticides cost (Table 2).

\section{Profitability of hybrid maize seed production}

The average seed yield was $3110 \mathrm{~kg} / \mathrm{ha}$ (Table 3). The yield was highest in NGO (3780 kg/ha) as compared to public agency (2352 kg/ha) and private company (3198 kg/ha) due to better land preparation and good soil conditions.

The average net return of maize seed production was Tk. 56574/ha. The net return was also higher for public agency (Tk. 78204/ha) than private company (Tk. 39088/ha) and NGO (Tk. 33246/ha) due to the fact that the public agency like BADC pay higher price for purchase hybrid maize seed than private company and NGO. The average benefit cost ratio of hybrid maize seed cultivation was 1.99. The benefit cost ratio was found highest in Public agency than private company and NGO.

\section{Comparative economic performance of hybrid seed and hybrid maize production}

Table 4 shows the comparative economic performance of hybrid seed and maize production. On an average, total cost of cultivation of hybrid seed and hybrid maize (non-seed) were found Tk. 63558 and Tk. 44436 per hectare. The cost of cultivation of hybrid seed was 40 percent higher than that of hybrid maize. Net 
returns were Tk. 56574 per hectare for hybrid seed and Tk. 28234 per hectare for non-seed, respectively. The former was 50 percent higher than the latter. Similarly, benefit cost ratios were 1.99 and 1.64, respectively on total cost basis. Similar results were found in case of return per labour.

Table 2. Cost of production of hybrid maize seed at farm level.

\begin{tabular}{|c|c|c|c|c|}
\hline Cost items & $\begin{array}{l}\text { Public } \\
\text { agency }\end{array}$ & $\begin{array}{c}\text { Private } \\
\text { company }\end{array}$ & NGO & $\begin{array}{c}\text { All } \\
\text { categories }\end{array}$ \\
\hline \multicolumn{5}{|l|}{ Human labour } \\
\hline Family & 5720 & 6500 & 7400 & 6540 \\
\hline Hired & 8789 & 8400 & 7100 & 8096 \\
\hline Total & 14509 (22) & $14900(25)$ & $14500(22)$ & $14636(23)$ \\
\hline \multicolumn{5}{|l|}{ Land preparation cost } \\
\hline Own & - & - & - & - \\
\hline Hired & 4830 & 4402 & 5024 & 4752 \\
\hline Total & $4830(7)$ & $4402(7)$ & $5024(7)$ & $4752(8)$ \\
\hline Seed & $10000(16)$ & $9500(16)$ & $11000(17)$ & $10166(16)$ \\
\hline Cowdung & $1574(2)$ & $1678(3)$ & $1371(2)$ & $1558(3)$ \\
\hline \multicolumn{5}{|l|}{ Chemical fertilizers } \\
\hline Urea & 3246 & 3150 & 3210 & 3204 \\
\hline TSP & 5478 & 5434 & 5410 & 5434 \\
\hline MP & 4160 & 3940 & 3740 & 3940 \\
\hline Gypsum & 1035 & 1130 & 1250 & 1140 \\
\hline Zink & 720 & 780 & 480 & 660 \\
\hline Borax & 300 & 250 & 200 & 250 \\
\hline Total & 14939 (23) & $14684(25)$ & $14290(22)$ & $14628(23)$ \\
\hline Insecticides & $1376(2)$ & $1194(2)$ & $1940(3)$ & $1503(2)$ \\
\hline \multicolumn{5}{|l|}{ Irrigation } \\
\hline Own & - & & & - \\
\hline Hired & 4859 & 2440 & 4786 & 4028 \\
\hline Total & 4859 (8) & $2440(4)$ & $4786(7)$ & $4028(6)$ \\
\hline Interest on operating capital & $1568(3)$ & $1422(2)$ & $1545(2)$ & $1511(2)$ \\
\hline Land use cost (Tk./ha) & $11181(17)$ & $9132(16)$ & $12016(18)$ & $10776(17)$ \\
\hline \multicolumn{5}{|l|}{ Gross cost } \\
\hline Total cash cost & 44793 (69) & $40620(68)$ & $44140(66)$ & $43178(68)$ \\
\hline Total variable cost & $52087(80)$ & $48798(82)$ & $52911(80)$ & $51271(81)$ \\
\hline Total cost & $\begin{array}{c}64836 \\
(100)\end{array}$ & $\begin{array}{c}59352 \\
(100)\end{array}$ & $\begin{array}{c}66472 \\
(100)\end{array}$ & $63558(100)$ \\
\hline
\end{tabular}

Figures in the parenthesis indicate the percentage of total cost 
Table 3. Profitability of hybrid maize seed production at farm level.

\begin{tabular}{lccccc}
\hline \multicolumn{1}{c|}{ Items } & $\begin{array}{c}\text { Public } \\
\text { agency }\end{array}$ & $\begin{array}{c}\text { Private seed } \\
\text { company }\end{array}$ & NGO & $\begin{array}{c}\text { All } \\
\text { categories }\end{array}$ \\
\hline Yield (kg/ha) & 2352 & 3198 & 3780 & 3110 \\
Price (Tk./kg) & 60 & 30 & 26 & 38 \\
Gross return (Tk./ha) & 141120 & 95940 & 98280 & 118180 \\
Grain & 1920 & 2500 & 1438 & 1952 \\
Stover & 143040 & 98440 & 99718 & 120132 \\
Total & & & & \\
Gross cost (Tk./ha) & 44793 & 40620 & 44140 & 43178 \\
Total cash cost & 52087 & 48798 & 52911 & 51271 \\
Total variable cost & 64836 & 59352 & 66472 & 63558 \\
Total cost & & & & \\
Gross margin (Tk./ha) & 98247 & 57820 & 55578 & 76954 \\
Total cash cost basis & 90953 & 49642 & 46807 & 68861 \\
Total variable cost basis & 78204 & 39088 & 33246 & 56574 \\
Net return (Tk./ha) & 2.21 & 1.56 & 1.50 & 1.99 \\
Benefit cost ratio & 672 & 433 & 454 & 439 \\
Return to labour (Tk./man-day) & & & & \\
\hline
\end{tabular}

Table 4. Comparative economic performance of hybrid seed and hybrid maize production.

\begin{tabular}{l|c|c|c}
\hline \multicolumn{1}{c|}{ Items } & $\begin{array}{c}\text { Hybrid } \\
\text { maize seed }\end{array}$ & Hybrid maize & $\begin{array}{c}\% \text { increase (+) } \\
\text { or decrease (-) }\end{array}$ \\
\hline Grain yield (kg/ha) & 3110 & 8000 & -60 \\
Sale price (Tk./kg) & 38 & 8.89 & +77 \\
Gross return (Tk./ha) & & & \\
$\quad$ Grain & 118180 & 71136 & +40 \\
$\quad$ Stover & 1952 & 1534 & +21 \\
$\quad$ Total & 120132 & 72670 & +40 \\
Gross cost (Tk./ha) & & & \\
$\quad$ Total cash cost & 43178 & 25732 & +40 \\
$\quad$ Total variable cost & 51271 & 34385 & +34 \\
$\quad$ Total cost & 63558 & 44436 & +30 \\
Gross margin (Tk./ha) : & & & \\
$\quad$ Total cash cost basis & 76954 & 46938 & +39 \\
$\quad$ Total variable cost basis & 68861 & 38285 & +44 \\
Net return (Tk./ha) & 56574 & 28234 & +50 \\
Benefit cost ratio & 1.99 & 1.64 & +18 \\
Return to labour (Tk./man-day) & 439 & 324 & +26 \\
\hline
\end{tabular}




\section{Problems to maize seed production}

The respondent maize seed farmers were asked about the constraints of maize seed production. The answers were arranged according to ranked values. It can be as revealed from the Table 6 that high price of seed was the first ranked constraint followed by lack of technical knowledge, high price, and non availability of fertilizers in time. The constraints slightly varied from organization to organization.

Table 5. Problems of hybrid maize seed production at farm level.

\begin{tabular}{l|c|c|c|c}
\hline \multirow{2}{*}{\multicolumn{1}{c|}{ Constraints }} & \multicolumn{4}{c}{ Rank value } \\
\cline { 2 - 5 } & $\begin{array}{c}\text { Public } \\
\text { agency }\end{array}$ & $\begin{array}{c}\text { Private } \\
\text { company }\end{array}$ & NGO & $\begin{array}{c}\text { All } \\
\text { categories }\end{array}$ \\
\hline 1. Lack of technical knowledge & 2 & 2 & 2 & 2 \\
2. Infestation of pest and diseases & 3 & 4 & 4 & 4 \\
3. High price of hybrid seed & 1 & 1 & 1 & 1 \\
4. Disturbances by birds and animals parrot & 5 & 6 & 5 & 5 \\
5. High price and non-availability of & 4 & 3 & 3 & 3 \\
$\quad$ fertilizer in time & 6 & 5 & 6 & 6 \\
6. Lack of capital & 6 &
\end{tabular}

\section{Conclusion and Recommendations}

The findings of the study indicated that hybrid maize seed production is profitable on the basis of its return to investment. The cost of production of hybrid maize seed under NGO was found higher than public agency and private company. But gross margin, net return and benefit cost ratio under public agency was found higher than private company, and NGO. Gross return was 40 percent higher in hybrid seed production than hybrid maize production.

Based on the findings of the study, the following recommendations can be made:

- BARI should give more emphasis to provide better parental lines and higher quantities to BADC and private organizations at a reasonable price.

- Technical and financial support should be provided to the contract growers through government and non-government organizations for production of good quality hybrid seed.

- Contract growers should be trained time to time to upgrade their knowledge of seed production.

- SCA should strictly monitor the quality of the seeds produced by BADC and private organizations. 


\section{References}

Anon. 2002. Nutritive value of Maize, Wheat, Rice, Banana Flower of Moucha, Taro, Giant, Taro etc. The Bangladesh Observer May 30, Page 4.

BBS. 2004. Year Book of Agricultural Statistics of Bangladesh, Ministry of Planning, Government of the Peoples' Republic of Bangladesh, Dhaka.

BBS. 2006. Year Book of Agricultural Statistics of Bangladesh, Ministry of Planning, Government of the Peoples' Republic of Bangladesh, Dhaka.

Pingali, P.L. and Shivaji Pandey. 2000. Meeting World Maize Needs Technological Opportunities and Priorities for the Public Sector. International Food Policy Planning and Research Institute, Stanford University, California 94305, USA.

Islam, M.M. 2006. Seed Distribution System in Bangladesh: An Analysis. Bangladesh J. Agril. Res. 31(1): 97-118. 